with large, apparently solitary primary liver cell tumours in non-cirrhotic livers should be considered firstly for resection and only secondarily for liver transplantation.

LHB was supported by a grant from the Cancer Research Campaign.

\section{References}

1 Lee NW, Wong J, Ong GB. The surgical management of primary carcinoma of the liver. World $\mathcal{F}$ Surg 1982;6:66-75.

Lim RC, Bongard FS. Hepatocellular carcinoma. Changing concepts in diagnosis and management. Arch Surg 1984;119:637-41.

3 Chlebowski RT, Tong M, Weissman J, et al. Hepatocellular carcinoma. Diagnostic and prognostic features in North American patients. Cancer 1984;53:2701-6. thde DC, Sherlock P, Winawer SJ, Fortner JG. Clinical manifestations of hepa-
toma: a review of 6 years' experience at a cancer hospital. Am $\mathcal{J}$ Med 1974; 56:83-91.

5 Zhaoyou T. A new concept of the natural course of hepatocellular carcinoma. Chin Med $\mathcal{F} 1981 ; 94: 585-8$.

6 Foster JH, Berman MM. Solid liver tumours. Philadelphia: W B Saunders, 1977. Ong GB, Chan PKW. Primary carcinoma of the liver. Surg Gynecol Obstet

8 Tsuzuki T, Ogata Y, Iida S, Shimazu M. Hepatic resection in 125 patients. Arch Surg 1984;119:1025-32

Adson MA, Weiland LH. Resection of primary solid hepatic tumours. Am f Surg

10 Fortner JG, Maclean BJ, $\mathrm{Kim} \mathrm{DK}$, et al. The seventies evolution in liver surgery watzuki S, Shaw BW, Starzl TE. Experience with 150 liver resections. Ann Surg 1983;197:247-53.

12 Bengmark S, Hafstrøm L, Jeppsson B, Sundquist K. Primary carcinoma of the liver: improvement in sight? World $\mathcal{F}$ Surg 1982;6:54-60.

13 Craig JR, Peters RL, Edmondson HA, Omata M. Fibrolamellar carcinoma of the liver: a tumour of adolescents and young adults with distinct clinicopathologic features. Cancer 1980;46:372-9.

14 Berman MM, Libbey NP, Foster JH. Hepatocellular carcinoma. Polygonal cell type with fibrous stroma-an atypical variant with favourable prognosis.

15 Paradinas FJ, Melia WM, Willconson ML, et al. High serum vitamin $B_{12}$ binding capacity as a marker of the fibrolamellar variant of hepatocellular carcinoma. Br Med F 1982;285:840-2.

16 Collier NA, Bloom SR, Hodgson HJF, Weinbren K, Lee YC, Blumgart LH. Neurotensin secretion by fibrolamellar carcinoma of the liver. Lancet 1984 ; :

$538-40$.
MacDougal BRD, Williams R. Indications and assessment for orthotopic liver transplantation. In: Calne RY, ed. Liver transplantation. London: Grune and Stratton, 1983:

18 Starzl TE, Iwatsuki S, Shaw BW, et al. Analysis of liver transplantation. Hepato-

$\log y$ 1984;4:47-9S.
Rolles K, Williams R, Neuberger J, Calne R. The Cambridge and King's College Hospital experience of liver transplantation. Hepatology 1984;4:50-5S , Brölsch $\mathrm{Ch}$, Wonigeit $\mathrm{K}$, et al. Experiences with liver transplanta-

21 tion in Hannover. Hepatology 1984;4:56-60S. statement: liver transplantation. Hepatology 1984;4:107-10S.

22 Couinaud C. Le foie. Etudes anatomiques et chirurgicales. Paris: Masson, 1957. Okamoto E, Kyo A, Yamanaka N, Tanaka N, Kuwata K. Prediction of the safe limits of hepatectomy by combined volumetric and functional measurements in patients with impared Wepatic function. Surgery 1984;85:586-91.

tumour and

biliary obstruction. Br F Surg $1979,66: 762-9$.

26 Porter R, Whelan J, eds. Hepatotrophic factors 1978. Amsterdam: Elsevier Excerpta Medica, 1978. (Ciba Foundation Symposium, No 55.)

27 Foster JH. Computing operative risk. Surgery 1984;95:631.

28 Okamoto E, Tanaka N, Vamanaka N, Toyosaka A. Results of surgical treatments of primary hepatocellular carcinoma: some aspects to improve long-term survival. World f Surg 1984;8:360-6.

29 Joishy SK, Balasegaram M. Hepatic resection for malignant tumours of the liver: essentials for a unified surgical approach. Am f Surg 1980;139:360-9

30 Huguet C, Nordinger B, Gallopin JJ, et al. Normothermic hepatic exclusion for .

Fortner JG, Kallum BO, Kim DK. Surgical management of hepatic vein occlusion by tumour. Arch Surg 1977;112:727-8.

32 Blumgart LH, Benjamin IS, Hadjis NJ, Beazley R. Surgical approaches to cholangiocarcinoma at confluence of hepatic ducts. Lancet $1984 ;$; :66-70.

33 Cunci $O$, Coste $T$, Vacher B, Delva E, Huguet $C$. Résection de la veine cave inférieure rétro-hépatique au cours d'une hepatectomie pour tumeur. Evolution favorable sans reconstruction veineuse. Ann Chir 1983;37:197-201.

34 Søreide O, Czerniak A, Bradpiece HA, Bloom S, Blumgart LH. Characteristics of fibrolamellar hepatocellular carcinoma: an experience of nine cases and a

(Accepted 5 fuly 1985)

\title{
Effectiveness of treatment with antihypertensive drugs and trends in mortality from stroke in the community
}

\author{
JAAKKO TUOMILEHTO, AULIKKI NISSINEN, EVA WOLF, JEF GEBOERS, TAPANI PIHA, \\ PEKKA PUSKA
}

\begin{abstract}
A study was made of the changes in the treatment of hypertension, in the effectiveness of that treatment, and in mortality from cerebrovascular stroke in men and women in two counties in Finland. One of these counties was North Karelia, where a comprehensive cardiovascular programme based in the community had been launched in 1972. Cross sectional surveys in large representative samples of the middle aged populations were carried out in 1972, 1977, and 1982. Average annual mortality from stroke adjusted for age was calculated for the two year periods 1971-2, 1977-8, and 1980-1.
\end{abstract}

\footnotetext{
Department of Epidemiology and North Karelia Project, National Public Health Institute, SF-00280 Helsinki, Finland

JAAKKO TUOMILEHTO, MD, PHD

AULIKKI NISSINEN, MD, PHD

EVA WOLF, MD, MRCPATH

TAPANI PIHA, MD

PEKKA PUSKA, MD, PHD
}

Division of Epidemiology, School of Public Health, University of Leuven, B-3000 Leuven, Belgium

JEF GEBOERS, LICSCI

Correspondence to: Dr Tuomilehto.
The proportion of hypertensive men being effectively treated for their hypertension increased in both areas from 1972 to 1977 and further from 1977 to 1982 . Mortality from stroke in middle aged men decreased in both areas during both observation periods. The proportion of hypertensive women being effectively treated greatly increased in both areas from 1972 to 1977. This was associated with a large decline in mortality from stroke. In North Karelia the proportion of women being effectively treated was remarkably high but decreased somewhat between 1977 and 1982; this decrease was associated with an increase in mortality from stroke in the women aged 35-64.

These results support the idea that effective antihypertensive treatment in the community is a major determinant of mortality from stroke in both men and women.

\section{Introduction}

The fact that high blood pressure is the most important risk factor in cerebrovascular stroke has been well documented both in Finland ${ }^{12}$ and elsewhere. ${ }^{3-7}$ Several clinical trials have shown that the risk of stroke can be reduced by lowering blood pressure in hypertensive patients by treatment with antihypertensive drugs. ${ }^{8-14}$ Reducing the risk of stroke has been a major argument for recommending and implementing large scale, 
even nationwide programmes to detect, treat, and follow up patients with hypertension. ${ }^{15-18}$ One of these programmes was implemented in North Karelia, Finland, in 1972 and has subsequently been carefully evaluated. ${ }^{1619-22}$ This paper looks at the changes in treatment with antihypertensive drugs and their association with changes in mortality from stroke in North Karelia.

\section{The North Karelia project}

One of the main subprogrammes of the North Karelia project was the community based programme for the control of hypertension. Its objectives were: to reorganise care of hypertension in a way that would maximise the efforts to detect, treat, and follow up all hypertensive patients of all ages in North Karelia; to organise health education of the patients and the whole population; to train the local health personnel; and to evaluate the feasibility, effects, and cost of the programme. ${ }^{1622}$ The coordinating office of the project, together with local experts, prepared guidelines for the detection, treatment, and follow up of hypertension. The decision about when treatment should be started and what kind of regimen should be given to individual patients was left to the clinical judgment of the local physicians responsible for treating the patients. ${ }^{16} 19-22$

During the first five years of the project (1972-7) the guidelines were closely adhered to and the criterion for giving drug treatment to middle aged patients was usually a diastolic pressure of about $100 \mathrm{~mm} \mathrm{Hg.}{ }^{19} 22$ After this original five year period care of hypertension in North Karelia was under less intensive supervision by the project team. At the same time national guidelines were issued that were somewhat less stringent than those prepared by the project team. Educational and research activities, as well as the follow up and evaluation of care of hypertension, still continued in North Karelia after 1977. The reorganisation and intensification of care of hypertension in the reference area (the county of Kuopio) started a few years later than in North Karelia and was developed particularly after 1977. Although only a restricted age range has been studied in the evaluation of the programmes, the actual intervention has covered the entire population of North Karelia.

\section{Subjects and methods}

\section{POPULATION SURVEYS}

The first survey was carried out in the spring of 1972 in North Karelia and a matched reference area (county of Kuopio). ${ }^{19} \mathrm{~A}$ random $6.6 \%$ sample was drawn from the populations of both areas using the national population register. The sample included only men and women aged 25-59. In 1977 another cross sectional survey was carried out in the two areas using an independent $6.6 \%$ random sample, including only men and women aged $30-64 .^{19}$ In the spring of 1982 a third survey was carried out, again using an independent random sample of these two populations. This time the samples were drawn from the age group 25-64, and the samples were stratified so that for each sex and 10 year age group the sample size would be about $500 .{ }^{23}$ Although sampling procedures were different, all of these samples were representative of the study populations. The adjustment for age had practically no effect on the results.

Each of the three surveys included a self administered questionnaire, an interview, and physical measurements. The same methods were used as far as possible, and in each survey the two areas were treated in the same way. A detailed description of the methodology has been given elsewhere. ${ }^{19} 23$

Casual blood pressure was measured on the right arm using a standard sphygmomanometer with the subject sitting. In the 1972 and 1977 surveys a cuff $23 \mathrm{~cm}$ long and $13 \mathrm{~cm}$ wide was used, ${ }^{20}$ and in the 1982 survey the cuff used was $42 \mathrm{~cm}$ long and $13 \mathrm{~cm}$ wide. The difference in the recorded blood pressure between long $(42 \mathrm{~cm})$ and short $(23 \mathrm{~cm})$ cuffs was examined in a subgroup of people in $1982 .{ }^{24}$ Blood pressure was measured after five minutes' rest, before venous puncture, and the measurement was made during one continuous deflation. The fifth phase (disappearance of Korotkoff sounds) was taken as the diastolic blood pressure. Blood pressure was recorded to the nearest $2 \mathrm{~mm} \mathrm{Hg}$. The criterion "under drug treatment" was defined as the reported use of antihypertensive drugs during the preceding seven days.

Subjects were considered to be hypertensive if their blood pressure was at least $175 \mathrm{~mm} \mathrm{Hg}$ systolic or $100 \mathrm{~mm} \mathrm{Hg}$ diastolic, or both, or if they were being treated with antihypertensive drugs. The participation rates in the 1972 survey were $94 \%$ in North Karelia and $91 \%$ in the reference area; in the 1977 survey $89 \%$ and $91 \%$, respectively; and in the 1982 survey $80 \%$ and $82 \%$, respectively. The criteria used to evaluate whether drug treatment was effective were: casual systolic blood pressure less than $175 \mathrm{~mm} \mathrm{Hg}$ and diastolic blood pressure less than $100 \mathrm{~mm} \mathrm{Hg}$ at the survey examination.

\section{MORTALITY DATA}

The data on deaths from stroke-that is, the disease category A85 430-438 of the International Classification of Diseases-in North Karelia and the reference area for the years 1971-81 were obtained from the Central Statistical Office of Finland. The diagnoses on the individual death certificates were reviewed according to the guidelines laid down by the World Health Organisation for the International Classification of Diseases and recertified by the signer if necessary. The eighth revision of the International Classification of Diseases, adopted in Finland in 1969, was used throughout the study. The population data were based on the national population register with continuous registration of births, deaths, and migration. The mid-year populations were used as denominators in computing the annual death rates.

Death rates adjusted for age for the age group 35-64 were calculated with the direct method, using Segi's European population in five year age groups as the standard. Average annual mortality fiom stroke was calculated for roughly the three times at which the population surveys were carried out. To reduce random error caused by variation in annual death rates the average annual rates were expressed as the means of the rates of two consecutive years (1971-2, 1977-8, and 1980-1). Unfortunately, we did not have access to the data on mortality after 1981, but it can be assumed that the situation concerning treatment in January to April 1982 reflected fairly closely that in $1980-1$, and there is no reason to believe that this introduced a major source of bias.

\section{Results}

Table I shows the numbers of people studied and the proportions with hypertension in the surveys in 1972, 1977, and 1982 in North Karelia and the reference area. The proportion of hypertensive subjects who were treated with antihypertensive drugs was about $14 \%$ in men and about $30 \%$ in women in 1972 in both areas. During 1972-7 the amount of treatment increased greatly so that by 1977 $51 \%$ of hypertensive men and $69 \%$ of hypertensive women in North Karelia were receiving treatment with drugs. In the reference area the increase was somewhat smaller. During 1977-82 a slight decrease

TABLE I-Number (\%) of hypertensive men and women aged 35-64, treated hypertensive patients, and patients whose hypertension was adequately controlled in North Karelia and reference area in 1972, 1977, and 1982*

\begin{tabular}{|c|c|c|c|c|c|c|}
\hline & \multicolumn{3}{|c|}{ North Karelia } & \multicolumn{3}{|c|}{ Reference area } \\
\hline & $1972 \dagger$ & 1977 & 1982 & $1972 \dagger$ & 1977 & 1982 \\
\hline \multicolumn{7}{|c|}{ Men } \\
\hline $\begin{array}{l}\text { All subjects studied } \\
\text { Hypertensive subjects }\end{array}$ & $\begin{array}{c}1475 \\
479 \\
(32 \cdot 5)\end{array}$ & $\begin{array}{c}1603 \\
442 \\
(27 \cdot 6)\end{array}$ & $\begin{array}{c}1202 \\
371 \\
(30 \cdot 9)\end{array}$ & $\begin{array}{c}2106 \\
680 \\
(32 \cdot 3)\end{array}$ & $\begin{array}{l}2372 \\
878 \\
(37)\end{array}$ & $\begin{array}{c}1021 \\
345 \\
(33 \cdot 8)\end{array}$ \\
\hline $\begin{array}{l}\text { Hypertensive patients } \\
\text { treated with anti- }\end{array}$ & $\begin{array}{l}67 \\
67 \\
(14)\end{array}$ & $\begin{array}{c}225 \\
(50 \cdot 9)\end{array}$ & $\begin{array}{c}172 \\
(46 \cdot 4)\end{array}$ & $\begin{array}{l}98 \\
(14 \cdot 4)\end{array}$ & $\begin{array}{l}327 \\
(37 \cdot 2)\end{array}$ & $\begin{array}{l}119 \\
(34 \cdot 6)\end{array}$ \\
\hline Hypertensive patients & $\begin{array}{l}19 \\
(4)\end{array}$ & $\begin{array}{c}104 \\
(23 \cdot 5)\end{array}$ & $\begin{array}{c}92 \\
(24 \cdot 8)\end{array}$ & $\begin{array}{c}25 \\
(3 \cdot 7)\end{array}$ & $\begin{array}{c}100 \\
(11 \cdot 4)\end{array}$ & $\begin{array}{c}60 \\
(17 \cdot 3)\end{array}$ \\
\hline \multicolumn{7}{|l|}{ with drug tr } \\
\hline $\begin{array}{l}\text { All subjects studied } \\
\text { Hypertensive subjects }\end{array}$ & $\begin{array}{c}1604 \\
632 \\
(39 \cdot 4)\end{array}$ & $\begin{array}{c}1779 \\
519 \\
(29 \cdot 2)\end{array}$ & $\begin{array}{c}1298 \\
362 \\
(27 \cdot 9)\end{array}$ & $\begin{array}{l}2198 \\
725 \\
(33)\end{array}$ & $\begin{array}{c}2641 \\
885 \\
(33 \cdot 5)\end{array}$ & $\begin{array}{l}1020 \\
326 \\
(32)\end{array}$ \\
\hline $\begin{array}{l}\text { Hypertensive patients } \\
\text { treated with anti- } \\
\text { hypertensive drugs }\end{array}$ & $\begin{array}{l}182 \\
(28 \cdot 8)\end{array}$ & $\begin{array}{r}359 \\
(69 \cdot 2)\end{array}$ & $\begin{array}{c}213 \\
(58 \cdot 8)\end{array}$ & $\begin{array}{c}231 \\
(31.9)\end{array}$ & $\begin{array}{c}487 \\
(55)\end{array}$ & $\begin{array}{c}188 \\
(57.7)\end{array}$ \\
\hline $\begin{array}{l}\text { Hypertensive patients } \\
\text { adequately controlled } \\
\text { with drug treatment }\end{array}$ & $\begin{array}{c}33 \\
(5 \cdot 2)\end{array}$ & $\begin{array}{c}211 \\
(40 \cdot 7)\end{array}$ & $\begin{array}{c}118 \\
(32 \cdot 6)\end{array}$ & $\begin{array}{c}61 \\
(8 \cdot 4)\end{array}$ & $\begin{array}{c}193 \\
(21 \cdot 8)\end{array}$ & $\begin{array}{c}108 \\
(33 \cdot 1)\end{array}$ \\
\hline
\end{tabular}

*Hypertension was diagnosed if systolic blood pressure was $\geqslant 175 \mathrm{~mm} \mathrm{Hg}$ or diastolic blood pressure $\leqslant 100 \mathrm{~mm} \mathrm{Hg}$, or both, or patient was being treated with antihypertensive drugs. Adequate control was classified as systolic blood pressur $<175 \mathrm{~mm} \mathrm{Hg}$ or diastolic blood pressure $<100 \mathrm{~mm} \mathrm{Hg}$ or both. +In 1972 age group was 35-59. 
was seen in the proportion of hypertensive men being treated with drugs in both areas. In North Karelian women the decrease was as much as $10.4 \%$, whereas the proportion of women in the reference area receiving treatment still slightly increased.

The proportion of patients with adequately controlled blood pressure among all hypertensive subjects was less than $10 \%$ in 1972 in both sexes and both areas. In 1977, however, this proportion had increased in North Karelia to $24 \%$ in men and $41 \%$ in women. In the reference area these proportions had become $11 \%$ in men and $22 \%$ in women. During 1977-82 the proportion of hypertensive patients with adequately controlled blood pressure increased slightly further in both areas in men and women in the reference area. In North Karelian women it fell from $41 \%$ to $33 \%$.

The average annual mortality from stroke adjusted for age in men decreased in such a way that at the end of the observation period it was similar in both areas (table II). The proportional mortality from

TABLE II-Annual mortality from stroke adjusted for age in men and women aged 35-64 in North Karelia and reference area at three specified times

\begin{tabular}{|c|c|c|c|c|c|c|}
\hline & \multicolumn{3}{|c|}{ North Karelia } & \multicolumn{3}{|c|}{ Reference area } \\
\hline & $1971-2$ & $1977-8$ & $1980-1$ & $1971-2$ & $1977-8$ & $1980-1$ \\
\hline \multirow{4}{*}{$\begin{array}{l}\text { Average total mortality/ } \\
100000 \\
\text { Average mortality from } \\
\text { stroke/100 } 000 \\
\text { Proportional mortality } \\
\text { from stroke }(\%)\end{array}$} & \multicolumn{3}{|c|}{ Men } & & & \\
\hline & 1434 & 1329 & 1216 & 1523 & 1294 & 1061 \\
\hline & 117 & 105 & 69 & 137 & 95 & 68 \\
\hline & $8 \cdot 2$ & 7.9 & $5 \cdot 7$ & 9.0 & $7 \cdot 3$ & 6.4 \\
\hline \multirow{4}{*}{$\begin{array}{l}\text { Average total mortality/ } \\
100000 \\
\text { Average mortality from } \\
\text { stroke/100 000 } \\
\text { Proportional mortality } \\
\text { from stroke }(\%)\end{array}$} & \multicolumn{3}{|c|}{ Women } & & & \\
\hline & 542 & 458 & 387 & 515 & 424 & 376 \\
\hline & 96 & 45 & 56 & 93 & 62 & 45 \\
\hline & $17 \cdot 7$ & $9 \cdot 8$ & 14.5 & $18 \cdot 1$ & $14 \cdot 6$ & $12 \cdot 0$ \\
\hline
\end{tabular}

stroke-that is, mortality from stroke as a proportion of total mortality-was $8 \%$ in North Karelia and $9 \%$ in the reference area in 1971-2. It decreased in both areas in men during both observation periods, being around $6 \%$ in 1980-1. The average annual mortality from stroke adjusted for age in 1971-2 was lower in women than men. A steep decline was observed during the first observation period in both areas. During the second observation period the mortality from stroke started to increase in North Karelia while it continued to decrease in the reference area. The proportional mortality from stroke in women was higher than that in men, being around $18 \%$ in both areas in 1971-2. It fell to $10 \%$ (45\% decrease) in North Karelia and to $15 \%(19 \%$ decrease) in the reference area in 1977-8. During the second period the proportional mortality from stroke increased by $47 \%$ in North Karelian women but continued to decrease in women in the reference area.

In men the death rates from stroke adjusted for age declined steadily in both areas during the entire observation period. The decline was similar in both North Karelia and the reference area. In North Karelian women the decline in the death rates from stroke adjusted for age was very steep during the first period (before 1977-8) but started to rise again thereafter. In the reference area mortality from stroke in women showed a steady decline during both periods.

Table II shows the patients whose hypertension was effectively treated as a percentage of all the hypertensive subjects. A consistent negative association between the rates of change, the average annual mortality from stroke, and the proportion of patients who were effectively treated was evident: as the proportion of patients whose hypertension was well controlled increased mortality from stroke declined. As the control of blood pressure worsened in North Karelian women between 1977 and 1982, however, mortality from stroke started to increase again.

\section{Discussion}

It is well known that the risk of dying of ischaemic heart disease and also of cerebrovascular disease is higher for men than women. As pointed out recently, this difference has been interpreted by some doctors as meaning that a less aggressive management of hypertension is needed in women. ${ }^{25}$ No difference in the association between high blood pressure and the incidence of stroke between men and women was found in either the Framingham study ${ }^{26}$ or the North Karelia study. ${ }^{2}$ Our results show that the incidence of stroke is higher in men than in women but that the proportional mortality from stroke in women is about twice that in men. The fact that more than one in 10 deaths among women aged $35-64$ is due to stroke indicates that the prevention of stroke is one of the most important aims of preventive medicine for middle aged women.

It is true that in practically all industrialised populations men have higher blood pressures than women between the ages of 15 and $45 .{ }^{27-30} \mathrm{High}$ blood pressure at a younger age-that is, the earlier exposure in men compared with women-probably contributes to the higher incidence of stroke in middle aged men. On the other hand, other risk factors for atherosclerosis and cerebrovascular stroke-for example, smoking and serum cholesterol concentrations-are more prevalent in men. They are also strongly clustered in hypertensive men but not in women. ${ }^{302}$ This clustering of risk factors may largely explain the higher incidence of myocardial infarction and stroke in men. Changes in other risk factors may also partly explain why in some populations the effect of reducing blood pressure by treatment with antihypertensive drugs has been more effective in men than in women..$^{13} 32$

Silman emphasised that the differences in risk, however, cannot be easily translated into differences in response to treatment to lower blood pressure. ${ }^{25}$ The few existing randomised therapeutic trials have not always been able to document an appreciably better outcome in the groups receiving intensive treatment compared with the reference groups. ${ }^{14}$ s1 This lack of benefit may be the result of more active participation of women in the reference groups. Awareness, treatment, and control of hypertension have usually been found to be better in women than in men. ${ }^{20}{ }^{21} 32{ }^{33}$ In eastern Finland control of hypertension was clearly better in women than in men ${ }^{21}$ even before the start of the North Karelia project in 1972 and the nationwide activities to control hypertension in 1977.

The better initial control in women did not hinder the reduction in mortality from stroke in North Karelian women by about $50 \%$ over a period of five to seven years. This reduction was associated with a simultaneous $50 \%$ increase in the number of women treated for hypertension and an eightfold increase in the proportion of women treated with drugs whose blood pressure was adequately controlled. Control of hypertension seemed to be easier and more effective in women compared with men. Our interpretation of this observation is that the fairly simple but systematic methods of detecting, treating, and following up hypertension will result in a pronounced reduction of complications of high blood pressure such as stroke in women. To achieve a similar reduction in mortality from stroke in men reductions of other risk factors for atherosclerosis-that is, smoking and serum cholesterol concentrations-will probably be required. In fact, such reductions were seen in both North Karelia and, to a lesser degree, the reference area. ${ }^{23}$

Some doctors and health authorities are worried about the costs of unnecessary treatment with antihypertensive drugs, especially in women. ${ }^{34-37}$ This has also been the case in Finland. This worry had a considerable influence on the recommendations of the Finnish National Blood Pressure Committee in 1977.38 The committee recommended that the criteria for drug treatment should be a diastolic blood pressure of $110 \mathrm{~mm} \mathrm{Hg}$ at repeated measurements in men and about $5 \mathrm{~mm} \mathrm{Hg}$ higher in women if no other risk factors for cardiovascular disease were identified. ${ }^{38} 39$ The different thresholds for treatment in the two sexes were based on the assumption that hypertensive women have a lower incidence of cardiovascular complications than hypertensive men. The high threshold for both sexes was possibly related to the economic implications as the Social Insurance Institution fully covers the costs of treatment with antihypertensive drugs in Finland. Drugs are provided free of charge for all hypertensive patients.

The increase in the number of hypertensive patients entitled 
to drugs free of charge has now levelled off, ${ }^{30} 40$ and the proportion of Finnish middle aged women with hypertension receiving treatment is declining. ${ }^{41} \mathrm{~A}$ reduction in treatment for hypertension took place in North Karelian women between 1977 and 1982. It may be true that there was some overtreatment of hypertensive women in North Karelia due to the intensive hypertension programme of the North Karelia project, but treatment has, unfortunately, been stopped in many women who woild have benefited from it, judging from the increase in mortality from stroke. From this point of view the worry about overtreatment may have been overemphasised. Alarmingly, since 1979 annual death rates from stroke in North Karelian women have increased. At the same time mortality from stroke has decreased in North Karelian men as well as in both sexes in the reference area, this decrease being associated with a further improvement in the effectiveness of treatment with antihypertensive drugs.

We have no reason to believe that the differences in observed mortality from stroke could be an artefact of changes in diagnostic measurements or the better reporting of deaths. The eighth revision of the International Classification of Diseases was used in Finland throughout the period from 1969 to 1981. Standardised diagnostic criteria for stroke recommended by the World Health Organisation ${ }^{42}$ and adopted by the North Karelia project have been used in North Karelia since 1972. ${ }^{119}$

It might be argued that the observed association between the change in mortality from stroke and the effectiveness of treatment with antihypertensive drugs in the North Karelian women is due to chance or random variation. The analyses, however, were based on 12 time-sex-area observations, and the association was remarkably consistent and in accordance with expectations.

Are there any other factors that might have contributed to the reversing of the previous decline in mortality from stroke in North Karelian women? Such factors could for instance be changes in smoking, serum cholesterol concentrations, obesity, alcohol intake, and salt intake. Fortunately, we were able to obtain reliable data on all these factors in both North Karelia and the reference area during our study. We know that salt intake decreased slightly in normotensive women in both areas ${ }^{43}$ and also in hypertensive men but unfortunately not in hypertensive women. ${ }^{44}$ Serum cholesterol concentrations have been decreasing in women. ${ }^{23}{ }^{43}$ Though smoking decreased appreciably in men, it increased slightly in women, but less than $10 \%$ of hypertensive women smoke. Slightly fewer women smoke in North Karelia than in the reference area. ${ }^{23}{ }^{43}$ The mean body mass index decreased slightly in women in both North Karelia and the reference area. ${ }^{45}$ Alcohol intake is increasing slightly in women, but the proportion of women who drink alcohol regularly-that is, at least once a week-is still less than $15 \% .{ }^{43}$ No appreciable differences in risk factors were seen that could explain the difference in the trends in mortality from stroke in women in North Karelia compared with the reference area.

Widespread treatment with antihypertensive drugs may carry some risks, and these should be kept in mind. Obviously, non-pharmacological intervention would be better than pharmacological intervention and should be preferred if equally good control of blood pressure could be achieved. Much research on this subject is urgently needed. The decisions concerning community based programmes for control of hypertension should be assessed on sound epidemiological evidence. Evidence from comprehensive investigations in North Karelia does not support the assumption that treatment of hypertension is less important in women than in men or that there is overtreatment of hypertensive women. Our findings give evidence against such beliefs. Some further evidence is expected from the trial being conducted by the Medical Research Council on mild hypertension in Great Britain. ${ }^{46}$ More direct evidence could also be obtained from a clinical trial in which hypertensive women in the mild category of hypertension being treated with drugs were randomised into two groups, one stopping the treatment and the other continuing it. Implementation of such a trial might not be easy for practical and ethical reasons. Such a "natural trial" has already been carried out in North Karelia, and the results are partly described in this paper.

\section{References}

1 Tuomilehto J, Salonen JT, Puska P, Salmi K, Nissinen A, Homan K. Profile of cerebral stroke in the population and the effect of preventive measures. diagnosis. Littleton: PSG Publishing Company, 1980:11-26.

2 Salonen JT, Puska P. Tuomilehto J, Homan K Relation of blood pressure, serum lipids and smoking to the risk of cerebral stroke-a longitudinal study in eastern Findand String to the risk of cere

$3 \mathrm{Kannel} W$, Dawber T, Cohen M, et al Vascular disease of the brain logical aspect. The Framingham study. Am $\mathcal{F}$ Public Health $1965 ; 55: 1355-66$ Kannel WB, Dawber TR, Sorlie P, et al. Components of blood pressure and risk of atherothrombotic brain infarction: the Framingham study. Stroke 1976;7:327-31.

Abu-Zeid HAH, Choi NW, Maini KK, Hsu P, Nelson NA. Relative role of factors associated with cerebral infarction and cerebral hemorrhage. Stroke 1977;8:106-12.

Callen PW, Keating RD, Lemak NA, Preslock MM. Long term changes in Jeshima H, Ida M, Shimamoto T, et al. Multivariate analysis of risk factors for stroke. Prev Med 1980;9:722-40.

8 Veterans Administration Study Group on Antihypertensive Agents. Effects of treatment on morbidity in hypertension. II. Results in patients with diastolic blood pressure averaging 115 through $129 \mathrm{~mm} \mathrm{Hg.} 3 A M A$ 1967;202:1028-34.

9 Veterans Administration Study Group on Antihypertensive Agents. Effects of treatment on morbidity in hypertension. II. Results in patients with diastolic blood pressures averaging 90 through $114 \mathrm{~mm} \mathrm{Hg}$. FAMA 1970;213:1143-52.

10 Carter B. Hypotensive therapy in stroke survivors. Lancet $1970 ; \mathrm{i}: 485-8$. changes in $A$, Dollery $\mathrm{C}$, Parry EMO. Prognosis of treated hypertension: changes in life expe
$1970 ; 39: 411-29$

$12 \mathrm{McF}$ ate Smith SW. Treatment of mild hypertension. Results of a ten-year intervention trial. Circ Res 1977;40:98-105.

13 Hypertension Detection and Follow-up Program Cooperative Group. Five year findings of the hypertension detection and follow-up program. I. Reduction in mortality of persons with high blood pressure, including mild hypertension. $A M A$

14 Management Committee of the National Heart Foundation of Australia. Report: the Australian therapeutic trial in mild hypertension. Lancet 1980;i:1261-7.

15 Borhani N. Implementation and evaluation of community hypertension programs. In: Paul O, ed. Epidemiology and control of hypertension.

16 Tuomilehto J, Puska P, Nissinen A. Hypertension programme of the North Karelia project. Scand f Soc Med 1976;4:67-70.

17 World Health Organisation. Primary prevention of essential hypertension. WHO Tech Rep Ser 1983; No 686

18 World Health Organisation. Hypertension related to health care-research priorities. Copenhagen: WHO Regional Office for Europe, 1980. (EURO reports and studies 32.$)$

19 Puska P, Tuomilehto J, Salonen J, et al. Community control of cardiovascular diseases. Evaluation of a comprehensive community programme for control of cardiovascular diseases in North Karelia Finland 1972-1977. Copenhagen:

Nissinen A. Evaluation of the come, 198.

Nissinen A. Evaluation of the community based hypertension programme of the North Karelia project, with special reference to the awareness and treatment Community Health 1979; Vol 2. (Kuopio Series.)

21 Tuomilehto J, Nissinen A, Salonen J, Kottke TE, Puska P. Community programme for control of hypertension in North Karelia, Finland. Lancet 1980; ii:900-4.

22 Nissinen A, Tuomilehto J, Elo J, Salonen JT, Puska P. Implementation of a hypertension control program in the county of North Karelia, Finland.

23 Puska $P$, Salonen JT, Nissinen A, et al. Change in risk factors for coronary heart disease during 10 years of a community programme (North Karelia project).

24 Nissinen A, Tuomilehto J, Puska P, Korhonen $H$. Ten-year results of hyperensive care in the community. Follow-up of the North Karelia hypertension control program. Unpublished.

25 Silman A. Hypertension in women: a separate case for treatment ? Br Med $\mathrm{J}$ 1984;289:1021-2.

26 Kannel WB, Wolf PA, Verter J, McNamara P. Epidemiologic assessment of the role of blood pressure in stroke. The Framingham study. $\mathcal{J} A M A$ 1970;214:

7 Epstein FH, Eckoff RD. The epidemiology of high blood pressure geographic distributors and etiological factors. In: Stamler J, Stamler R, eds. The 28 Rosner B, Hennekens CH, Kass EH, Miall WE. Age specific correlation analysis of longitudinal blood pressure data. Am 3 Epidemiol 1977;106:306-13.
Task Force on Blood Pressure Control in Children. Report. Pediatrics 1977; 59 (suppl):797-819.

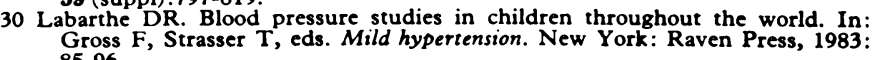

30a Salonen JT, Puska P, Kottke TE, Heinonen OP. Clustering of coronary risk factor patterns in eastern Finland. Int $\mathcal{F}$ Epidemiol 1981;10:203-10

31 Hypertension Detection and Follow-up Program Co-operative Group. Five year findings of the hypertension detection and follow
Mortality by race, sex and age. $\mathcal{F} A M A 1979 ; 242: 2572-7$.

32 Wilber J, Barrow J. Hypertension-a community problem. Am f Med 1972;52 653-63.

33 Keil U, Döring A, Stieber J. Community studies in the Federal Republic of Germany. In: Gross F, Strasser T, eds. Mild hypertension. Recent advances. New York: Raven Press, 1983

34 Hodes C, Rogers PA, Everitt MG. High blood pressure: detection and treatment by general practitioners. Br Med F $1975 ;$ ii:674-7.

35 Eisalo A, Tötterman K. Verenpainetaudin tarpeeton lääkehoito. Suomen Lääkärilehti 1978;33:769.

36 Finnerty FA. Step-down therapy in hyper ustan HP, Page IH, Tarazi RC, Frohlich

ED. Arterial pressure responses to omiteamietintö. Verenpainetoimikunnan mietintö. (Proposal by the Committee for High Blood Pressure). Helsinki: The Government's Printing Office, 1977

46 Tuomilehto J, Nissinen A, Puska P, Salonen J. Community control of hyper-
tension in Finland. In: Bulpitt C, ed. Handbook of hypertension. Vol 6. tension in Finland. In: Bulpitt C, ed. Handbook of hypertension. Vol 6.
Epidemiology of antihypertensive drugs. Amsterdam: Elsevier Science Publishers,

(1) (1) (1) .

年 .

.

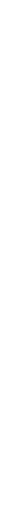


40 Aromaa A, Kohonnut verenpaine ja sen kansanterveydellinen merkitys Suomessa. Helsinki : Social Security Institute publications, $1981: 17$.

Vol B2. Helsinki: National Public Health Institute, 1984

42 Hatano S, WHO Collaborative Study Group. Experience from a multicenter stroke register: a preliminary report. Bull WHO 1976;54:540-53.

43 Tuomilehto J, Puska P, Nissinen A, et al. Community-based prevention of hypertension in North Karelia, Finland. Ann Clin Res 1984;16(suppl 38):

44 Pietinen $P$, Tanskanen A, Nissinen A, Tuomilehto J, Puska P. Changes in dietary habits and knowledge concerning salt during a community-based

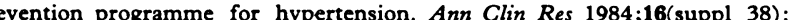
$154-9$.

45 Jalkanen I Tuomilehto J Salonen JT, Nissinen A, Pietinen P, Puska P. Changes in body mass index during a ten year follow-up of the adult general population of East Finland [Abstract]. The IV International Congress on Obesity. New York, USA 1983: October 5-8, Abstract book:40a.

46 Medical Research Council Working Party on Mild to Moderate Hypertension. Randomised controlled trial of treatment for mild hypertension: design and pilot trial. Br Med F 1977; i:1437-40.

(Accepted 2 fuly 1985)

\title{
Palmoplantar pustulosis and smoking
}

\author{
CONOR J O'DOHERTY, CECILIA MACINTYRE
}

\begin{abstract}
A multicentre case-control study of 216 patients with palmoplantar pustulosis and 626 controls with miscellaneous dermatoses showed a considerably higher prevalence of smoking in the group with palmoplantar pustulosis. This was the first indication that smoking may be an important factor in this skin disease, possibly by affecting the inflammatory responses of the skin.
\end{abstract}

\section{Introduction}

Palmoplantar pustulosis is a chronic condition of unknown cause characterised by sterile yellow pustules that fade into brown macules, lying in areas of erythema and scaling (figure). Although at one time it was thought to be a variant of psoriasis, the current trend is to separate the two conditions. ${ }^{1}$ In Europe it affects women about three times as often as men, ${ }^{2}$ but in Japan the sex ratio of those affected is fairly even. ${ }^{3}$ ' It is recalcitrant to treatment, particularly with topical agents. Responses to systemic agents such as photochemotherapy, ${ }^{\circ}$ retinoids, ${ }^{\circ}$ and tetracyclines $^{7}$ are temporary, and the condition usually relapses after treatment is stopped. This suggests that the causative factor is still at work and that such treatments are merely suppressive. One of us (CO'D) noted that many patients with palmoplantar pustulosis smoked cigarettes, and a pilot study suggested an association between palmoplantar pustulosis and smoking.8 A retrospective multicentre case-control survey was therefore undertaken to investigate the prevalence of smoking in patients with palmoplantar pustulosis and in controls.

\section{Patients and methods}

The disease indexes of five departments of dermatology in Edinburgh, London, Cardiff, Manchester, and Airdrie were examined and the names and hospital numbers of all patients presenting with palmoplantar pustulosis since 1980 extracted. Their home address and that of their general practitioner as well as the date of onset of palmoplantar pustulosis and date of first presentation at the skin clinic were recorded from their clinical notes. Each case of palmoplantar pustulosis was then matched for age, sex, and date of presentation with three controls

\footnotetext{
Department of Dermatology and the Medical Computing and Statistics Unit, University of Edinburgh

CONOR J O'DOHERTY, MSC, MRCP, lecturer in dermatology

CECILIA MACINTYRE, BSC, MSC, lecturer in statistics
}

Correspondence to: Dr Conor J O'Doherty, Prince of Wales Hospital, London N15 4AW. with miscellaneous dermatoses. Three suitable controls could not be found for nine cases $(4 \%)$, however, and only two controls were therefore selected, while nine other patients with palmoplantar pustulosis over the age of 60 were each matched with four controls because of the possibility that some selected controls might have died. In total 216 cases and 626 controls were selected from the five centres. Permission to approach their patients was received from the general practitioners of those selected as cases and controls, and the study was approved by the medical ethical committees of the respective centres.

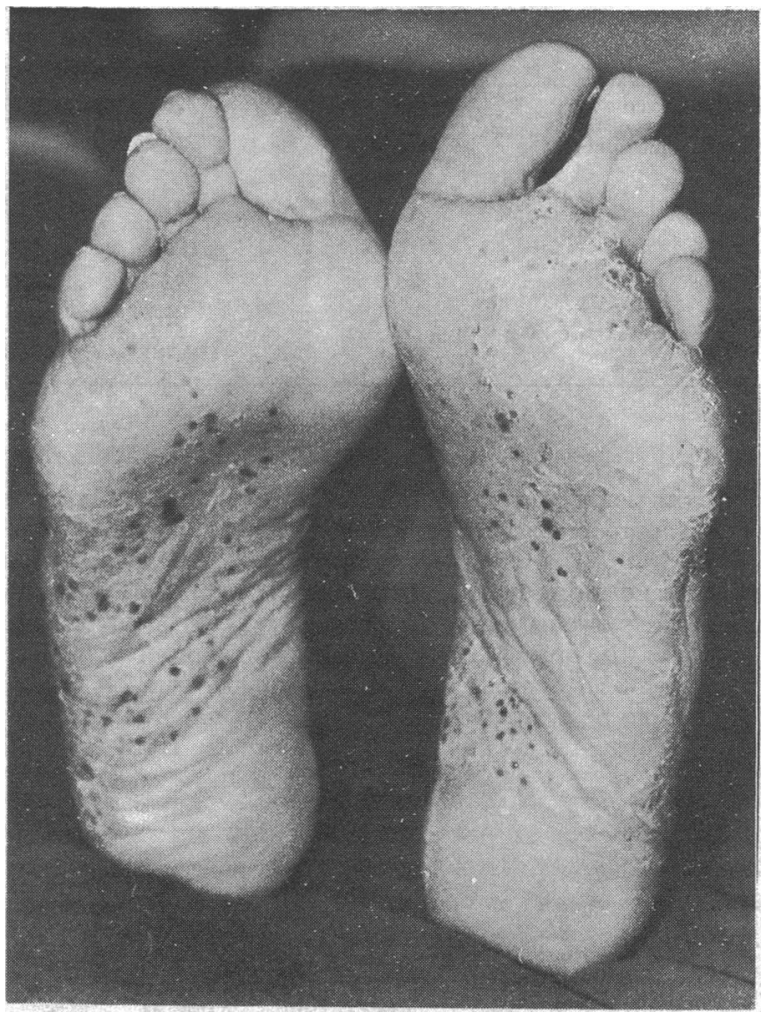

Case of palmoplantar pustulosis.

A letter seeking their cooperation, a stamped addressed envelope, and a questionnaire were sent to all subjects. The questionnaire was designed to ensure that it was possible to deduce from it the smoking habits of the control patients at the time of onset of skin disease in their matched cases. All subjects were asked their occupation to assess social class, and a question on consumption of alcohol was included in the questionnaire for distraction.

For the purpose of this study smokers were arbitrarily defined as people who had ever smoked more than one cigarette a day, one small cigar a day, or one ounce of pipe tobacco a month for longer than a 